\title{
ANALISIS KADAR KARBOHIDRAT PADA BIJI TUMBUHAN PAKIS HAJI (Cycas rumphii Miq)
}

\author{
John Elton Ngarbingan
}

\author{
Staf Pengajar Pada SMU Negeri 3 Tual, Kabupaten Maluku Tenggara
}

\author{
E-mail: eltonsanny@gmail.com
}

\begin{abstract}
Background: Food is one of the basic needs needed by the body every day in certain amounts as a source of energy and nutrients. In the body, food substances containing carbon elements can be used as energy-forming materials, one of which is carbohydrates obtained from various food sources. Pakis haji (Cycas rumphii Miq) is one type of Pakis haji (Cycas) commonly found in the archipelago that grows on different substrates. In Maluku people know Pakis Haji with the title of "king fruit", and use the leaves as vegetables, and the seeds processed into food.

Methods: Sampling in Karangguli Village, Aru Islands District and analysis of carbohydrate levels in Basic Chemistry Laboratory of Faculty of Natural Science, Pattimura University of Ambon. The sample in this research is 5 gram of Pakis haji seed plant with the variable of carbohydrate level on the seed of haji fern plant. Carbohydrate analysis was performed using spectrophotometric method.

Result: The result obtained is carbohydrate content on haji fern seed growing on soil substrate with lime stone is $50.95 \%$ and growing on sand substrate is $44.92 \%$. These results indicate that the seeds of Pakis haji can be used as a major source of carbohydrates.

Conclusion: Based on the result of research and data analysis, it can be concluded that carbohydrate level on Pakis haji seed (Cycas rumphii Miq) growing on soil substrate with lime stone is $50.95 \%$ and growing on sand substrate is $44.92 \%$.
\end{abstract}

Keywords: carbohydrates, Cycas rumphii Miq.

\begin{abstract}
Abstrak
Latar Belakang: Pangan merupakan salah satu kebutuhan pokok yang dibutuhkan oleh tubuh setiap hari dalam jumlah tertentu sebagai sumber energi dan zat-zat gizi. Di dalam tubuh, zat-zat makanan yang mengandung unsur karbon dapat dipergunakan sebagai bahan pembentuk energi, salah satunya adalah karbohidrat yang diperoleh dari berbagai sumber pangan. Pakis haji (Cycas rumphii Miq) adalah salah satu jenis pakis (Cycas) yang umumnya ditemukan di Nusantara yang tumbuh pada substrat yang berbeda. Di Maluku masyarakat mengenal Pakis haji dengan sebutan "buah raja", dan memanfaatkan daunnya sebagai sayuran, serta bijinya diolah menjadi bahan makanan.

Metode: Pengambilan sampel pakis haji di Desa Karangguli, Kabupaten Kepulauan Aru dan analisis kadar karbohidrat pada laboratorium Kimia Dasar Fakultas MIPA Universitas Pattimura Ambon. Sampel dalam penelitian ini adalah 5 gram biji tumbuhan pakis haji dengan variabel kadar karbohidrat pada biji tumbuhan pakis haji. Analisis karbohidrat dilakukan menggunakan metode spektrofotometri.

Hasil: Hasil yang diperoleh yaitu kadar karbohidrat pada biji pakis haji yang tumbuh pada substrat tanah dengan batuan kapur adalah 50,95 \% dan yang tumbuh pada substrat pasir adalah 44,92\%. Hasil ini menunjukkan bahwa biji pakis haji dapat dijadikan sebagai sumber karbohidrat utama.

Kesimpulan: Berdasarkan hasil penelitian dan analisis data maka dapat disimpulkan bahwa kadar karbohidrat pada biji pakis haji (Cycas rumphii Miq) yang tumbuh pada substrat tanah dengan batuan kapur adalah 50,95\% dan yang tumbuh pada substrat pasir adalah 44,92 \%.
\end{abstract}

Kata kunci: karbohidrat, Cycas rumphii Miq. 


\section{PENDAHULUAN}

Pangan merupakan salah satu kebutuhan pokok yang dibutuhkan tubuh setiap hari dalam jumlah tertentu sebagai sumber energi dan zat-zat gizi. Hubungan erat antara makanan dengan kesehatan manusia telah lama diakui, sejak tahun 1970 para pembuat kebijakan di dunia menyadari bahwa arti makanan lebih luas dari sekedar untuk memelihara dan meningkatkan kesehatan saja. Energi sangat diperlukan pada setiap aktivitas mahluk hidup, tanpa adanya energi berarti tidak ada kehidupan. Sebagian besar porsi dari makanan / pakan yang dikonsumsi oleh manusia atau hewan digunakan untuk memenuhi kebutuhan energi, karena reaksi anabolik dan katabolik dalam tubuh memerlukan energi.

Diketahui bahwa di dalam tubuh zat-zat makanan yang mengandung unsur karbon dapat dipergunakan sebagai bahan pembentuk energi, salah satunya adalah karbohidrat. Karbohidrat merupakan penyusun utama cadangan makanan tumbuh- tumbuhan, karbohidrat memegang peran penting dalam alam karena merupakan sumber energi utama bagi manusia dan hewan yang harganya relatif murah (Almatsier, 2001).

Menurut neraca bahan makanan Tahun 1990 yang dikeluarkan oleh biro pusat statistik, di Indonesia energi berasal dari karbohidrat merupakan $72 \%$ jumlah energi rata-rata sehari yang dikonsumsi oleh penduduk. Di negara-negara maju seperti Amerika Serikat dan Eropa Barat, angka ini lebih rendah, yaitu rata-rata 50\% (Almatsier, 2001).

Pada umumnya penduduk Indonesia, yang sebagian besar terdiri atas petani, masih mengandalkan konsumsi makanannya pada makanan pokok. Makanan pokok yang digunakan adalah beras, jagung, umbi-umbian (terutama singkong dan ubi jalar), dan sagu. Penggunaan makanan pokok didasarkan atas ketersediaannya di daerah bersangkutan yang pada umumnya berasal dari hasil usaha tani keluarga dan kemudian berkembang menjadi kebiasaan makan daerah tersebut.

Salah satu makanan sebagai sumber karbohidrat adalah biji pakis haji. Pakis haji adalah salah satu jenis pakis (Cycas) yang umum ditemukan di Nusantara, pakis haji menyebar di seluruh Kepulauan Indonesia, mulai dari Jawa, Nusa Tenggara, Sulawesi, Maluku, dan Papua. Asalnya diperkirakan dari Maluku (Anonim, 2011).

Di Maluku khususnya Kepulauan Aru, Kei, Seram Bagian Timur (Pulau Geser, Gorong) dan Maluku Barat Daya (Pulau Romang), masyarakat mengenal pakis haji dengan sebutan buah raja". Tumbuhan ini tumbuh liar di sekitar pesisir pantai dan di pedalaman pada substrat tanah dengan batuan kapur dan pasir, bahkan ada yang ditanam sebagai tanaman hias di pekarangan rumah. Masyarakat memanfaatkan daunnya sebagai sayuran, dan daging bijinya diolah menjadi bahan makanan yang dapat langsung dimakan atau dibuat tepung yang tidak kalah nilainya dengan zat tepung lainnya.

Hal yang menarik adalah kadar karbohidrat dalam biji tumbuhan pakis haji belum diteliti karena perhatian masyarakat hanya untuk dikonsumsi sehingga perlu untuk mengembangkannya sebagai model riset yang bernilai ilmiah dan bermutu. Bertolak dari landasan pemikiran di atas maka perlu diketahui secara ilmiah tentang kadar karbohidrat yang terkandung dalam biji pakis haji (Cycas rumphii Miq).

\section{MATERI DAN METODE}

Penelitian ini dilaksanakan pada bulan Mei 2012 dengan lokasi penelitian terbagi atas 2 (dua) yaitu: Pengambilan sampel pakis haji di Desa Karangguli, Kabupaten Kepulauan Aru dan analisis kadar karbohidrat pada laboratorium Kimia Dasar Fakultas MIPA Universitas Pattimura Ambon. Sampel dalam penelitian ini adalah 5 gram biji tumbuhan pakis haji dengan variabel kadar karbohidrat pada biji tumbuhan pakis haji. Analisis karbohidrat dilakukan menggunakan metode spektrofotometri.

\section{HASIL DAN PEMBAHASAN Hasil}

Hasil pengukuran absorbansi pada biji tumbuhan pakis haji. untuk setiap pengulangan dapat dilihat pada Tabel 1. 
Tabel 1. Absorbansi Cuplikan

\begin{tabular}{|c|c|c|c|c|c|}
\hline \multicolumn{2}{|c|}{ Sampel } & $\begin{array}{c}\text { Konsentrasi } \\
(\mathrm{mg} / \mathrm{l})\end{array}$ & $\begin{array}{c}\text { Rata-rata } \\
\text { Konsentrasi } \\
(\mathrm{mg} / \mathrm{l})\end{array}$ & $\begin{array}{c}\text { Absorbansi } \\
\text { Cuplikan (nm) }\end{array}$ & $\begin{array}{c}\text { Rata-rata } \\
\text { Absorbansi } \\
\text { (mg/l) }\end{array}$ \\
\hline \multirow{5}{*}{1} & $A^{1}$ & & \multirow{5}{*}{26,4} & & \multirow{5}{*}{0,475} \\
\hline & $\bigcup_{1}$ & 28,8333 & & 0,518 & \\
\hline & $U_{2}$ & 24,9444 & & 0,448 & \\
\hline & $U_{3}$ & 25,7222 & & 0,462 & \\
\hline & $\begin{array}{l}U_{4} \\
A^{2}\end{array}$ & 26,2777 & & 0,472 & \\
\hline \multirow{4}{*}{2} & $U_{1}$ & 25,1666 & & 0,452 & \multirow{4}{*}{0,428} \\
\hline & $U_{2}$ & 23,7222 & 23,8 & 0,426 & \\
\hline & $U_{3}$ & 23,0555 & & 0,414 & \\
\hline & $\bigcup_{4}$ & 23,4444 & & 0,421 & \\
\hline
\end{tabular}

Keterangan:

$\mathbf{U}=$ Ulangan

$\mathbf{A}^{1}=$ Biji pakis haji yang tumbuh di substrat tanah dengan batuan kapur

$\mathbf{A}^{2}=$ Biji pakis haji yang tumbuh di substrat pasir

Tabel 2. Hasil Analisis Kadar Karbohidrat Pada Biji Tumbuhan Pakis Haji.

\begin{tabular}{cccccc}
\hline Sampel & $\begin{array}{c}\text { Berat } \\
\text { Sampel } \\
(\mathbf{g r})\end{array}$ & $\begin{array}{c}\text { Berat } \\
\text { Karbohidrat } \\
(\mathbf{m g})\end{array}$ & $\begin{array}{c}\text { Kadar } \\
\text { Karbohidrat } \\
(\%)\end{array}$ & $\begin{array}{c}\text { Rata-rata } \\
\text { Karbohidrat } \\
(\%)\end{array}$ \\
\hline & $\mathbf{A}^{1}$ & & & & \\
1 & $-U_{1}$ & 0,5047 & 288,333 & 57,1296 & 50,95 \\
& $-U_{2}$ & 0,5300 & 249,444 & 47,0649 & \\
& $-U_{3}$ & 0,5447 & 257,222 & 47,2226 & \\
& $-U_{4}$ & 0,5013 & 262,777 & 52,4191 & \\
& $\mathbf{A}^{2}$ & & & & \\
& $-U_{1}$ & 0,5452 & 251,666 & 46,1603 & \\
& $-U_{2}$ & 0,5356 & 237,222 & 44,2908 & \\
2 & $-U_{3}$ & 0,5206 & 230,555 & 44,2864 & \\
& $-U_{4}$ & 0,5216 & 234,444 & 44,9470 & \\
\hline
\end{tabular}

Nilai kadar karbohidrat pada biji tumbuhan pakis haji dapat dilihat pada Tabel 2. Dari hasil perhitungan maka rata-rata kadar karbohidrat yang terdapat pada biji tumbuhan pakis haji yang tumbuh di substrat tanah dengan batuan kapur adalah 50,95\%, dan rata-rata kadar karbohidrat yang terdapat pada biji tumbuhan pakis haji yang tumbuh di substrat pasir adalah 44,92\%.

\section{Pembahasan}

Berdasarkan hasil analisis data maka, diperoleh kadar karbohidrat pada biji tumbuhan pakis haji yang tumbuh pada substrat tanah dengan batuan kapur adalah $50,95 \%$ dan yang tumbuh pada substrat pasir adalah 44,92 \%. Terdapatnya kadar karbohidrat pada biji pakis haji menunjukkan bahwa biji pakis haji dapat dijadikan sebagai sumber karbohidrat utama. Menurut Almatsier (2001), menyatakan nilai karbohidrat pada beberapa bahan makanan antara lain : ketela pohon $34,7 \%$, ubi jalar merah $27,9 \%$, kentang $19,2 \%$, kacang kedelei 34,8\%, selanjutnya Winarno (2004), menjelaskan sumber karbohidrat utama bagi bahan makanan manusia adalah serealia dan umbi-umbian, misalnya kandungan pati dalam beras $78,4 \%$, jagung $72,4 \%$, singkong $34,6 \%$ dan talas $40 \%$,

Fila (2012) menjelaskan bahwa biji pakis haji yang matang terdiri dari kulit biji yang keras dan dan endosperm yang kaya akan bahan cadangan makanan. Selama proses pematangan, biji akan mengalami kekurangan cairan, sehingga nusellus 
menjadi tertekan dan membentuk tudung tipis seperti perisperm di atas endospern. Selama proses pematangan biji, cadangan makanan seperti pati, lemak, dan protein terdapat dalam endosperma, penyimpanan cadangan makanan bertepatan dengan perkembangan embrio di dalam biji, juga Campbell dkk., (2002) menjelaskan bahwa sementara embrio berkembang, biji akan menumpuk protein, minyak, dan pati dan menahan zat-zat makanan dalam tempat penyimpanan sampai biji tersebut berkecambah. Dengan demikian adanya kandungan karbohidarat yang tersimpan dalam biji tumbuhan pakis haji dapat dikonsumsi sebagai sumber nutrisi atau energi bagi tubuh.

Salah satu faktor yang menunjang nutrisi tumbuhan adalah fotosintesis, karena karbohidrat merupakan hasil akhir dari proses fotosintesis. Laju fotosintesis dipengaruhi oleh beberapa faktor yang terdiri atas faktor genetik (faktor internal) dan faktor lingkungan (faktor eksternal) (Lakitan, 2011).

Di samping perbedaan metabolisme fiksasi $\mathrm{CO}_{2}$, umur daun (stadia perkembangan daun) juga akan mempengaruhi laju fotosintesis. Faktor internal lain yang dapat mempengaruhi laju fotosintesis adalah laju translokasi hasil fotosintesis (fotosisintat, dalam bentuk sukrosa) dari daun ke organ-organ penampung yang berfungsi sebagai lumbung (sink)

Faktor lingkungan yang mempengaruhi laju fotosintesis yaitu ketersediaan air, ketersediaan $\mathrm{CO}_{2}$, pengaruh cahaya, dan pengaruh suhu. Selain fotosintesis beberapa faktor terpenting yang mempengaruhi nutrisi tumbuhan dan lingkungan tanah pada tumbuhan adalah : atmosfer tanah, suhu tanah, air tanah, larutan dan reaksi tanah, jasad tanah serta humus.

Tanah dapat dianggap sebagai lapian tipis alami yang menutupi permukaan bumi yang menunjang kehidupan. Tanah terbentuk dari batuan atau dari bahan induk lain melalui proses pelapukan, tanah menyediakan medium untuk pertumbuhan akar tumbuhan dan tempat untuk bertaut, tanah juga menyediakan air dan garamgaram mineral (Ewusie, 1990). Tekstur dan komposisi kimia tanah merupakan faktor utama yang menentukan jenis tumbuhan apa yang dapat tumbuh dengan baik pada suatu lokasi tertentu. Tumbuhan yang tumbuh secara alamiah pada jenis tanah tertentu dapat beradaptasi terhadap kandungan mineral dan tekstur tanah tersebut dan mampu menyerap air dan mengekstraksi nutrien esensial dari tanah itu (Campbell dkk., 2002).

Dari data yang diperoleh terdapat perbedaan kadar karbohidrat pada kedua sampel, hal ini disebabkan perbedaan tempat tumbuh (substrat) yaitu tanah (dengan batuan kapur) dan pasir, perbedaan substrat itu juga berpengaruh terhadap tersedianya unsur hara bagi tumbuhan itu sendiri. Tjwan, (1965) dalam Sutedjo dan Kartasapoetra (2010), menyatakan unsur hara merupakan ion atau molekul tertentu yang diserap tumbuhan bagi keperluan faal atau fisiologinya. Menurut Blair tahun (1979) dalam Agustina (2004), terdapat tiga faktor penting yang mempengaruhi tersedianya unsur hara di dalam tanah yaitu suplai dari fase padat, $\mathrm{pH}$ tanah, dan suplai air.

Kemampuan tanah untuk mengatur suplai tersedianya unsur hara dari fase padat bervariasi tergantung jenis unsur haranya. Tiga faktor penting yang berkaitan dengan fase padat adalah serapan atau permukaan tukar anion dan kation, lambatnya ketersediaan unsur hara di dalam larutan garam, dan bahan organik.

Tersedianya unsur hara sangat erat hubungannya dengan $\mathrm{pH}$ yang diukur dalam skala log. Secara umum ketersediaan maksimum pada kisaran $\mathrm{pH} 6-7$. Pada $\mathrm{pH}$ yang rendah ketersediaan $\mathrm{N}, \mathrm{P}, \mathrm{K}, \mathrm{S}, \mathrm{Ca}$, $\mathrm{Mg}$, dan Mo sangat rendah, sedangkan pada $\mathrm{pH}$ yang sangat tinggi $\mathrm{P}, \mathrm{K}, \mathrm{S}$ dan $\mathrm{B}$ serta $\mathrm{Mo}$ cukup banyak tersedia.

Tanah yang dibentuk di atas bahan induk yang mengandung proporsi $\mathrm{CaCO}_{3}$ yang tinggi (batu kapur, kapur dan beberapa bahan lain serta endapan glasial) cenderung mempunyai nilai $\mathrm{pH}$ sekitar 7 atau lebih, walaupun selama pembentukan tanah ionion $\mathrm{Ca}^{2+}$ akan tercuci, yang akibatnya secara bertahap akan menurunkan pH. Sekalipun demikian, tanah-tanah berkapur disangga (dibuffer) secara baik oleh $\mathrm{CaCO}_{3}$ dan hanya dalam kondisi ekstrem $\mathrm{pH}$ akan turun dibawah 5. selain itu kapur aktif juga merupakan salah satu faktor yang berperan dalam pengendalian nitrifikasi (Poerwowidodo, 1992). 
Hermanto (1991), menjelaskan bahwa $\mathrm{pH}$ pada lokasi pengambilan sampel (desa Karangguli) adalah 5,8 - 7,8 dan memiliki kadar $\mathrm{N}, \mathrm{P}, \mathrm{K}$ cukup tinggi selain itu perbandingan $\mathrm{C} / \mathrm{N}$ ideal atau sangat baik, sehingga dapat dimungkinkan untuk pengembangan lahan pertanian, perkebunan maupun usaha lain.

Status air tanah berpengaruh terhadap ketersediaan unsur hara bagi tanaman. Kandungan air tanah yang rendah dapat mengakibatkan rendahnya konsentrasi unsur hara yang ada di dalam larutan tanah (Agustina, 2004). Jumlah air yang ditahan tanah terutama tergantung pada iklim, dan khususnya pada kelebihan presipitasi yang melebihi efapotransirasi $(E<P)$, pengecualiaannya terjadi pada habitat kering yang tidak umum, sebagai contoh pada tanah dangkal atau berpasir (Fitter dan Hay, 1998).

Kebutuhan air pada tumbuhan dapat dipenuhi melalui tanah dengan jalan penyerapan oleh akar. Besarnya air yang diserap, oleh akar tumbuhan sangat tergantung pada kadar air tanah dan konsisi lingkungan di atas tanah. Pada tumbuhan pesisir yang tumbuh pada substrat pasir, jika butiran pasirnya besar-besar karenanya mempunyai rongga yang besar pula di antaranya, maka air apapun, baik yang berasal dari hembusan garam atau dari pengendapan biasa, dengan cepat teralir ke bawah melalui pasir yang tidak atau sedikit menambat air untuk tumbuhan yang tumbuh pada pesisir. Berbeda dengan substrat tanah yang mengandung humus, humus meningkatkan daya tambat air pada tanah sehingga menyediakan air bagi tumbuhan (Ewusie 1990), humus mencegah tanah liat menjadi lengket satu sama lain dan membentuk tanah gembur yang menahan air namun masih cukup berpori untuk terjadinya aerasi akar yang mencukupi (Campbell dkk., 2002). Tjitrosomo, (1990) menyatakan tanah liat dapat menahan air sebanyak tiga sampai enam kali lebih banyak bila dibandingkan dengan tanah berpasir.

\section{KESIMPULAN}

Berdasarkan hasil penelitian dan analisis data maka dapat disimpulkan bahwa kadar karbohidrat pada biji pakis haji (Cycas rumphii Miq) yang tumbuh pada substrat tanah dengan batuan kapur adalah 50,95\% dan yang tumbuh pada substrat pasir adalah $44,92 \%$.

\section{DAFTAR PUSTAKA}

Agustina, L. 2004. Dasar Nutrisi Tanaman. Jakarta: Rineka Cipta.

Almatsier, S. 2001. Prinsip Dasar Ilmu Gizi. Jakarta: Gramedia Pustaka Utama.

Campbell N.A, Reece J.B, Mitcheel L.G. 2002. Biologi. Jilid 2. Erlangga: Jakarta

Ewusie, J.Y. 1990. Pengantar Ekologi Tropika. Penerbit ITB: Bandung.

Fila, 2012. Reproduksi Tumbuhan (http://filaz one. blogspot. Com /2012/02/ embrilogi-n-reproduksitumbuhan. html). Diakses 06 Juni 2012.

Fitter, A.H. dan Hay R.K.M. 1998. Fisiologi Lingkungan Tanaman. Yogyakarta: Gadjah Mada University Press.

Hermanto, B. 1991. Analisis Geomorfologi Untuk Evaluasi Kemampuan Lahan di Kawasan Pesisir Kepulauan Aru, Maluku Tenggara. Perairan Maluku Tenggara. : $99-110$

Poerwowidodo, M. 1992. Telaah Kesuburan Tanah. Bandung: Angkasa.

Sutedjo, M.M. dan Kartasapoetra, A.G. 2010. Pengantar IImu Tanah. Jakarta: Rineka Cipta.

Tjitrosomo, S.S. 1990. Botani Umum 2. Bandung: Angkasa.

Winarno, F. G. 2004. Kimia Pangan dan Gizi. Jakarta: Gramedia Pustaka Utama

Lakitan, B. 2011. Dasar-dasar Fisiologi Tumbuhan. Jakarta: Raja Grafindo Persada. 